\title{
Attractor States, Control Parameters, and Co-Adaptation in Instructed L2 Inferential Comprehension: a Design-Based Research Study of a Critical Reading Intervention
}

\author{
Estados atratores, parâmetros de controle, \\ e co-adaptação no ensino da compreensão \\ inferencial em L2: uma pesquisa design- \\ based de intervenção de leitura crítica
}

Moisés Damián Perales Escudero*

Universidad de Quintana Roo

Chetumal - Quintana Roo / Mexico

ABSTRACT: Previous L1 and L2 research on inferential comprehension has tended to follow a quantitative orientation. By contrast, L2 research on critical reading is qualitative and tends to ignore inferences. This paper presents a qualitative, design-based study of a critical reading intervention focused on promoting generative rhetorical inferences and investigating co-adaptation and emergence of new meaning-making capacities. Complexity theory (CT) constructs were used to research processes of co-adaptation between the participants' comprehension and the teacher-researcher's understanding of learning and instructional needs. Identification of attractor states and control parameters in classroom discourse were used to explore unpredicted factors influencing the participants' inferential comprehension and further refine the intervention. The results indicate that rhetorical genre knowledge acted as a control parameter driving the students' comprehension to attractor states characterized by implausible inferences, and that this knowledge explains the emergence of pragmatic meaning (rhetorical inferences) from semantic meaning. The paper illustrates the usefulness of CT constructs in doing design-based research qualitatively in a manner that informs both theory and practice.

KEYWORDS: complexity theory, design-based research, genre, inferential comprehension, critical reading, EFL.

*moisesd@umich.edu 
RESUMO: As pesquisas anteriores em L1 e L2 sobre compreensão inferencial tendem a uma orientação quantitativa. Por outro lado, a pesquisa sobre leitura crítica em L2 é qualitativa e tende a ignorar as inferências. Este artigo apresenta um estudo qualitativo (design-based research) sobre uma intervenção de leitura crítica com foco na promoção de geração de inferências retóricas, investigando a co-adaptação e a emergência de capacidades de produção de novos significados. Os construtos da teoria da complexidade foram usados ??para investigar processos de co-adaptação entre a compreensão de aprendizagem e necessidades instrucionais dos participantes e do professor pesquisador. A identificação de estados atratores e de parâmetros de controle no discurso da sala de aula foram utilizados para explorar a influência de fatores imprevisíveis na compreensão dos participantes e refinar ainda mais a intervenção. Os resultados indicam que o conhecimento do gênero retórico atuou como parâmetro de controle conduzindo a compreensão dos alunos para os estados atratores caracterizados por inferências implausíveis, e que este conhecimento explica a emergência do significado pragmático (inferências retóricas) a partir do significado semântico. $\mathrm{O}$ artigo ilustra a utilidade de construtos da teoria da complexidade para realizar pesquisa qualitativa de modo a fornecer subsídios teóricos e práticos.

PALAVRAS-CHAVE: teoria da complexidade, design-based research, gênero, compreensão inferencial, leitura crítica, inglês como língua estrangeira.

\section{Introduction}

This paper is framed by two emerging research paradigms in applied linguistics and, more broadly, education: Complexity Theory (CT) and design-based research (DBR). Both CT and DBR have emerged in the context of increased questioning of the positivist and post-positivist epistemologies that have characterized research and discourse in many sub-fields of applied linguistics and education. The discourse of DBR has been located primarily in education rather than applied linguistics. Specifically, DBR scholars seek to develop new forms of conducting research and interventions that are responsive to local conditions and help to address localized learning needs, partly by bringing about refined understandings of such conditions and needs, while informing theory in the process (SCHOENFELD, 2006). The responsiveness of DBR lies in its commitment to bringing about changes in teaching and learning by producing educational designs that change conditions and meet needs (GREENO, 2006). DBR is then focused on producing innovative educational interventions and informing theory.

What, then, is the relationship of DBR to applied linguistics and CT? And, what do applied linguists and language teachers stand to gain from a consideration of this question? The work of Larsen-Freeman and Cameron 
(2008) suggests that the answers lie in a reconceptualization of the processes of learning and teaching a foreign language - or a native language, for that matter - as processes of co-adaptation (see definition below) emerging from the interaction of several complex systems framed by specific, global learning ecologies. Larsen-Freeman and Cameron present a number of methodological suggestions to keep research design on complex systems consistent with complexity theory. Amongst them are ethnography, design-based research, and microdevelopmental experiments.

The first part of this paper offers a theoretical discussion of the relationship between DBR, CT, and applied linguistics/foreign language learning and teaching. The second part of the paper presents empirical findings from a CT-inspired DBR study of critical reading that I conducted in the context of a college-level EFL discourse analysis class at a Mexican university (PERALES ESCUDERO, 2011). The goal of the intervention that constituted the subject of the study was to teach learners how to read US political opinion texts critically using constructs and procedures of SystemicFunctional Linguistics and rhetoric. This paper reports only on the part of the intervention focusing on Attitude analysis (MARTIN; WHITE, 2005) or analyses of the linguistic-cum-discursive expression of emotions and evaluations and its contribution to cohesion and coherence.

\section{CT, DBR and Applied Linguistics}

Originating in the biological and mathematical sciences, CT deals with systems that consist of the interaction of multiple components, or subsystems. A discussion of CT in the context of classroom learning must take into account at least three levels or scales of analysis: individual cognition, distributed cognition in the classroom, and the curricular and sociocultural forces that impact such cognition. The variegated patterns of interaction between these systems give rise to learning ecologies that constitute the foci of CT-inspired educational research and DBR.

Although complexity scholars disagree on the features a system must display to be considered complex, Stephens (2011) argues convincingly that scalar emergence is the key property distinguishing complex systems from non-complex ones. Emergent properties are those that arise from the synergetic interaction of sub-systems existing at several scales. Discoursal meaning is a case in point: the meaning of an utterance issues from the interaction between morphemes-graphemes, lexicogrammar, and D/discourse. 
Meaning is present at each level of the scale. As language users move up the hierarchy, lower-level meanings are integrated into higher-level ones and new aspects of meaning emerge. Non-linearity is also a feature of discoursal meaning: small changes at any scale can trigger vast changes in the meaning of an utterance that diffuse across the different scales. Further, the same utterance can give rise to different interpretations. This emergent property of language is evidence that language is a complex system (KRETZSCHMAR, 2009; LARSEN-FREEMAN; CAMERON, 2008; STEPHENS, 2011).

Like language, neural activity as a correlate of cognitive processes has been shown to display scalar emergence and non-linearity (BROWN, 1991; HANLON, 1991; MAINZER, 1994; DÍAZ, 2011). In classrooms, the brain activity of individuals, as observed in their behavior, is constantly being influenced by discourse-mediated interaction with other individuals. The resulting discursive activity is an emergent property of the discourse-mediated interaction between the systems of individuals brains. In turn, the patterns of neural activation in individuals are likely to vary with the flow of discursive activity in the classroom, leading to observable behaviors that may give rise to modifications in the discursive activity via patterned interaction with other individuals. From this perspective, learning lies in the emergence of new patterned processes ["procesos pautados", (DÍAZ, 1997, 2011)] of neural, discursive, and bodily activity in the context of interaction. Patterned processes are psycho-physical processes that unfold through space and time in non-linear ways. Interested readers are encouraged to refer to Díaz (1997, 2000, 2007, 2011) for a full review of patterned processes as a construct integrating brain activity and observable behavior. For my purposes, it is sufficient to assume that these processes develop interactively and adaptively through time (DÍAZ, 2011, p. 181). "Learning" here must not be understood as the achievement of curricular outcomes. From the perspective presented here, a classroom situation leading to, for example, a teacher's moving from assigning homework to not assigning homework because students will never do it anyway, is a kind of learning on the part of the teacher.

Two points need to be considered in order to tease out the relationship between CT and DBR. The first one is that the brain and bodily/discursive activities of teachers and students bear the influence of sociocultural patterns of activity. Lessons are organized in culturally recognizable ways. People in classrooms assume roles as teachers and students that are infused with values and expectations that are reflected in their discourse (i.e. the I-R-E sequence). 
Students' community literacy practices influence their sociocognitive activity when reading and writing at school, as well as their expectations and motivations vis-à-vis literacy. Teachers also bring their own literacy practices, expectations, motivations, and understandings. The curriculum (both manifest and hidden), frames classroom activity, instantiates larger societal forces and struggles, and influences students' and teachers' cognition in overt and covert ways. The classroom is thus an open system.

The second one is that learning is not unidirectional: it is not only students that learn in response to teacher- and curriculum-initiated activities; teachers may learn too in response to student-initiated activities. Coadaptation is another name for these processes of reciprocal changes.

Also called co-evolution, "co-adaptation is change in a system that is motivated by change in another, connected system... teachers and students coadapt in classroom behavior and discourse" (LARSEN-FREEMAN; CAMERON, 2008, p. 21). Thus, co-adaptation refers to a process of reciprocal influences between systems leading to changes in those systems and in other systems they may be a part of. Co-adaptation offers a way to capture the influences that individual learners and groups of learners may exert over curricular aspects such as the materials used, the time allotted to tasks, and the kinds of scaffolding provided. Such influences may lead to changes in learning goals, teaching procedures, and so on. For this reason, co-adaptation is a useful construct to consider when doing DBR, where a chief concern is to document influences on the emergent design of pedagogical solutions (COLLINS, 1999) so that specific learning ecologies can be better understood and more functional solutions can be offered to situated learning needs (COBB et al., 2003; SCHOENFELD, 2006).

I would like to propose the term "interpretive repertoire" as a metaphor to refer to the various forms of cognition, or patterned processes, that are involved in reading comprehension and presumably co-adapt with reading comprehension lessons. The concept of interpretive repertoire highlights the potential for patterned processes to assemble in different, changing configurations during discrete acts of reading, in a process akin to soft-assembly (THELEN; SMITH, 1994). In any given such act, components of the overall repertoire or system may remain inactive while others are activated and de-activated as the reading task proceeds. The construct "interpretive repertoire" also distinguishes between the system of comprehension (the overall repertoire) and instances of comprehension, or the interpretations of particular texts 
constructed by specific readers in specific situations. From this perspective, comprehension ability is not a stable constant; rather, it is an emergent property of the interaction between components of the interpretive repertoire and the reading task at hand, including text features and reading purposes.

Rather than using a single treatment and post-tests, design-based research is "an iterative process in which changes in the design [of an intervention] are made in response to experience of using the program [the intervention] in local circumstances" (GREENO, 2006, p. 799). As LarsenFreeman (2007) has pointed out, recent shifts in the goals of design experiments from an emphasis on hypothesis testing (e.g. COBB, 2001) to one on accounting for learning processes (COLLINS, 1999; LOBATO, 2003) and generating domain specific-theories (DESIGN-BASED RESEARCH COLLECTIVE, 2003; EDELSON, 2002) align design-based research with CT's interest on retrodiction, or the retrospective description of the trajectory of a system "from which we try to reconstruct the elements, interactions, and change processes of the system" (LARSEN-FREEMAN; CAMERON, 2008, p. 231). This emphasis on retrodiction comes from the realization that complex systems involve a large "unknowableness" factor: the non-linearity of complex systems, and the invisibility of forces leading them to certain attractor states make them "unpredictable in the conventional sense of predictability" (LARSEN-FREEMAN; CAMERON, 2008, p. 231). Thus, change in complex systems and the forces leading to it can be described only retrospectively, which is "the central goal of a complexity approach" (LARSEN-FREEMAN; CAMERON, p. 231). Two CT constructs are useful in investigating these changes: attractor states and control parameters.

Attractor states are "particular modes of behaviors that the system prefers” (LARSEN-FREEMAN; CAMERON, 2008, p. 49), or recurring, regular configurations of the interpretive repertoire. An example of an attractor state occurs when, for example, readers repeatedly arrive to similar inferences or follow similar inferential strategies for a family of related reading tasks.

In CT, the term "control parameter" refers to elements of a complex system that strongly influence the system's behavior. For example, textbooks and curricula, by privileging certain kinds of texts and interpretations of those can control classroom talk as well as strongly influence the emergence of new patterned processes. Also in classrooms, teacher's understandings, beliefs and actions can be a powerful control parameter driving the system of classroom discourse to certain states, which in turn can have an influence on students' 
learning. The control parameters of comprehension may be invisible, and identifying them is important for educational interventions because such identification tells investigators what moves the system and, therefore, what needs to be changed in order to alter the system's behavior in the desired ways.

The previous discussion of co-adaptation begs the question of what coadapts in the context of a DBR study. Co-adaptation occurs naturally in the context of any classroom, and there is certainly an intention on the part of the teacher that students will learn. However, in the context of a DBR study, the researcher(s) conducting the study explicitly seek to adapt features of the intervention to better meet learning needs. Without using the term "coadaptation," DBR scholars have developed a conceptual apparatus in order to describe and explain systematically these processes of change.

At present, there isn't a set of unified procedure and criteria for design-based research (SCHOENFELD, 2006). However, common features of design experiments include iterative design (COBB et al., 2003), an emphasis on pragmatic, data-based theory building (DESIGN-BASED RESEARCH COLLECTIVE, 2003; EDELSON, 2002; LARSEN-FREEMAN; CAMERON, 2008) and a focus on learning processes rather than outcomes (LOBATO, 2003; SCHOENFELD, 2006). Edelson (2002) suggests that it is through the formulation of initial, domain-specific theories, or "prototheories" (DESIGNBASED RESEARCH COLLECTIVE, 2003, p. 5) that design-based research addresses the determination of learning goals and the planning of teaching procedures. A goal of design based research is to refine these prototheories by feeding into them the knowledge gained from the implementation and iterative design of an intervention. The resulting theories (prototheories + learning from implementation) are called "domain theories" by Edelson (2002). See FIG. 1 for a representation of the process.

Prototheories can be usefully classified in three kinds: learning needs prototheories, learning outcomes prototheories, and instructional prototheories. The former two address the question "what should be learned?" whereas the latter provides an initial means to consider the question "how should it be organized for teaching?” (PETRINA, 2004).

According to Edelson (2002, p. 109), "a design process often begins with a perceived problem or opportunity and an idea for how to respond to it". From this perceived problem, the designer constructs a characterization of the challenges posed by the design context, or initial problem analysis. This problem analysis is a learning needs prototheory. Once an initial problem analysis exists, the design researcher assembles a description of the outcomes 
to be achieved as a result of the intervention produced by design research. This is the outcomes prototheory. In order to bridge the gap between the needs and the outcomes, the design researcher formulates a set of principles and hypotheses from relevant available theories, empirical results, and intuitive understandings of the target domain, in this case critical reading. ${ }^{1}$ This is the instructional prototheory. The three kinds of prototheories are influenced by theoretical framework $(s)$ that the researcher uses to construe the learning needs and interpret data.

As a result of the generation and analysis of the three prototheories, an initial design solution is created that represents the proposed means to address the needs identified in the problem analysis in a manner that brings about the desired outcomes. These means include specific pedagogical materials and forms of discursive interaction organized in a curricular sequence. This intervention is implemented and changes are made to it iteratively as perceptions of needs for change arise from theory-informed reflections and participants' articulated feedback. The end-product of implementation prior to reflection on further modifications, or the state of the intervention as implemented, is called "intermediate design solution" (EDELSON, 2002). In Edelson's design-based research framework, once a cycle of implementation is over, data analysis leads to three kinds of outcomes: a final design solution, a domain theory, and a design framework. A domain theory describes the learning challenges in a design context and the outcomes to be attained by an intervention in that context. It issues from the refinement of prototheories in post-implementation analysis. A final design solution incorporates findings from implementation data analysis. This "final" design solution, however, can be further taken through subsequent rounds of iterative design. A design framework is a collection of design principles and tasks that can be generalized to other, similar teaching/learning situations. This cycle is presented in graphic form in FIG. 1.

\footnotetext{
${ }^{1}$ Drawing on the work of Wallace $(1992,1999,2003)$ and Kress (1989), I define critical reading as deep engagement with a text that includes close attention to language, generative rhetorical inferences, and critique of ideologies. Generative rhetorical inferences are inferences about unstated authorial positions, intentions, assumptions, and targeted/constructed audiences. They are generative because they require reasoning rather than information retrieval from the text (KINSTCH, 1998). While critiquing and resisting ideology were also addressed by the intervention, the focus of this paper is on generative rhetorical inferences and Appraisal analysis.
} 


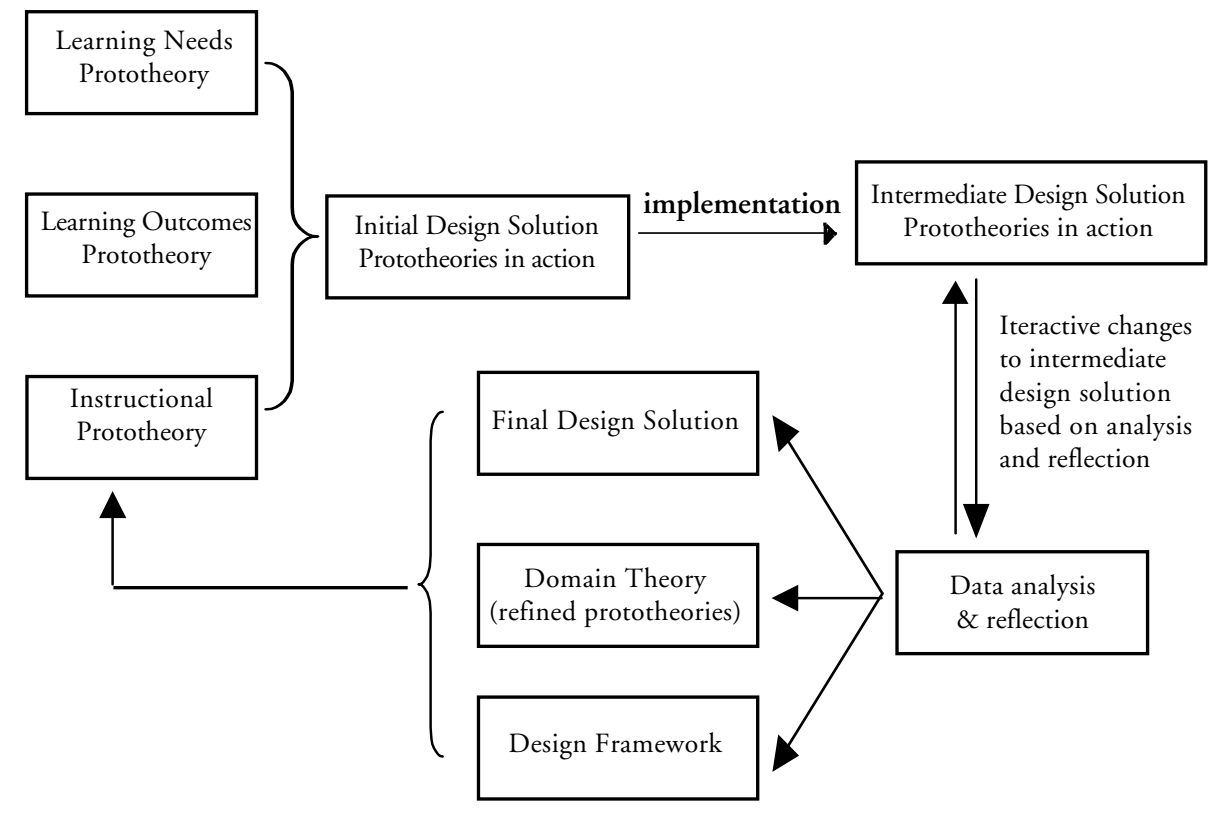

FIGURE 1 - Design-Based Research Cycle

Due to the instability in DBR methods, what counts as a valid DBR experiment is up for grabs. So far, DBR scholars have tended to use quantitative methods to assess student learning and report learning gains (e.g. KLEIN; ROSE, 2010). Drawing on the proposals by Larsen-Freeman and Cameron (2008), I propose that a qualitative, quasi-ethnographic approach using thick descriptions of multiple sources of classroom data is more fitting for examining and reporting co-adaptation processes between an intervention's prototheories and learners' interpretive repertoires. One should also not lose sight that the evolving prototheories also reflect learning on the part of the DBR researcher, and a qualitative approach is also more appropriate for capturing this dimension.

\section{The study}

This paper reports on a DBR intervention aiming at improving the critical reading skills of a group of college-level Mexican EFL teacher trainees. The study addressed the following two research questions: 1) How do features of the intervention and the learners' interpretive repertoires co-adapt?; 2) What attractor states and control parameters operating in the learners' interpretive repertoires can be identified in classroom discourse? 
The intervention was motivated by a needs analysis reported in Perales Escudero (2011). In this analysis, it was found that in-service Mexican EFL teachers at the University of Central Mexico (UCM, a pseudonym) experienced difficulties when attempting to infer rhetorical and ideological aspects of authentic, ideologically charged, on-line political opinion texts written in English for American and Canadian audiences. These texts were used at a UCM to teach EFL.

Analyses of texts and think-aloud-protocols revealed that infelicitous inferences were underpinned by shortcomings in processing evaluative language at the discourse level. This finding echoes findings by L2 reading researchers showing that $\mathrm{L} 2$ readers have difficulty processing meaning across large segments of text, focusing too much on local meanings instead (STANLEY, 1984; PRETORIOUS, 2005). The reading behavior of these Mexican teachers also underscores the issues encountered by $\mathrm{L} 2$ readers when confronted with texts issuing from a different cultural context: in the absence of relevant background knowledge, they need to rely almost exclusively on language processing to reconstruct textual meaning (KODA, 2005). As discussed by Perfetti, Marron and Foltz (1996), knowledge of how language works discursively is critical for making inferences related to author's implied political positions, intentions, and ideologies. That this knowledge is relevant for making this kind of inferences is also suggested by the work of scholars in Critical Discourse Analysis (e.g. FAIRCLOUGH, 1995, 2003; CHOULIARAKI; FAIRCLOUGH, 1999).

Nevertheless, EFL reading instruction at UCM, the setting of the pilot study, and the University of Southern Mexico (USM, the setting of the DBR study), focuses heavily on teaching background knowledge and vocabulary and asking post-reading comprehension questions. This way of teaching EFL reading is typical of the communicative approach (HAN; D'ANGELO, 2007), and has been challenged on the grounds that it does not develop EFL learners' ability to learn from texts on their own (BERNHARDT, 2011). It also doesn't intervene in the learners' text processing directly (GIBBONS, 2002; HAZELRIGG, 2009). This pedagogical practice can be particularly unhelpful for learners whose L1 literacy experiences have not prepared them for the literacy tasks they face in the L2 classroom. Reading ideologically-charged political opinion texts issuing from a different cultural context is a case in point for the participants in this study. There is evidence that literacy instruction in the public Mexican education system does not address critical reading or argumentative writing (PEREDO MERLO, 2011; HERNÁNDEZ, 2008; BUSSENIERS et al., 2011; PERALES ESCUDERO, 2010, 2011). Yet, Mexican EFL learners are exposed 
to texts that require critical reading through the Internet and through EFL pedagogical practices. Moreover, the kinds of discussions that occur around hotbutton issues such as abortion and gay marriage in the US tend to have a strong impact on similar discussions in Mexico, where many of the US positions and arguments are reproduced (AGUILAR, 2002). Thus, training pre-service Mexican EFL teachers to read this kind of texts critically is ecologically valid. Put together, these considerations constitute this study's learning needs prototheory.

Accordingly, I designed an outcomes prototheory and an instructional prototheory. A series of pedagogical meditational means (WERTSCH, 1993) were collected and/or designed to instantiate the instructional prototheory in classroom activity. These meditational means and their sequencing constitute the initial design solution. The prototheories and initial design solution are presented in TAB. 1.

\section{TABLE 1}

Learning prototheories and initial design solution

\begin{tabular}{|c|c|c|c|}
\hline $\begin{array}{l}\text { Problem Analysis/Learning } \\
\text { Prototheory }\end{array}$ & $\begin{array}{l}\text { Desired outcomes/Learning } \\
\text { outcomes prototheory }\end{array}$ & $\begin{array}{l}\text { Means to outcome/ } \\
\text { Instructional Prototheory }\end{array}$ & $\begin{array}{l}\text { Initial Design Solution/ } \\
\text { Mediational means }\end{array}$ \\
\hline $\begin{array}{l}\text { Difficulty in identifying } \\
\text { attitude patterns in } \\
\text { target genre }\end{array}$ & $\begin{array}{l}\text { Participants will be able } \\
\text { to identify and parse } \\
\text { attitude patterns }\end{array}$ & $\begin{array}{l}\text { - Appraisal analysis of inscribed } \\
\text { and invoked attitude and } \\
\text { scope/domination patterns } \\
\text { (Attitude analysis) } \\
\text { - Oral scaffolding } \\
\text { (questions/comments) }\end{array}$ & $\begin{array}{l}\text { - Texts } \\
\text { - Attitude DO } \\
\text { - Verbal scaffolding } \\
\text { - Attitude visuals } \\
\text { - Lesson plans }\end{array}$ \\
\hline $\begin{array}{l}\text { Difficulty in inferring } \\
\text { authorial position }\end{array}$ & $\begin{array}{l}\text { - Participants will be able } \\
\text { to infer authorial position }\end{array}$ & - Attitude analysis & $\begin{array}{l}\text { - Texts } \\
\text { - Attitude DO } \\
\text { - Verbal scaffolding } \\
\text { - Critical reading worksheets } \\
\text { - Lesson plans }\end{array}$ \\
\hline $\begin{array}{l}\text { Absence of inferences } \\
\text { about target/constructed } \\
\text { audience }\end{array}$ & $\begin{array}{l}\text { Participants will be able } \\
\text { to infer a text's target/ } \\
\text { constructed audience }\end{array}$ & $\begin{array}{l}\text { - Attitude analysis } \\
\text { - Oral scaffolding }\end{array}$ & $\begin{array}{l}\text { - Texts } \\
\text { - Attitude DO } \\
\text { - Verbal scaffolding } \\
\text { - Critical reading worksheets } \\
\text { - Lesson plans }\end{array}$ \\
\hline $\begin{array}{l}\text { Difficulty in identifying } \\
\text { source alignment }\end{array}$ & $\begin{array}{l}\text { - Participants will be able } \\
\text { to identify authorial } \\
\text { alignment of sources }\end{array}$ & $\begin{array}{l}\text { - Appraisal analysis of attribution } \\
\text { options (engagement analysis) } \\
\text { - Oral scaffolding }\end{array}$ & $\begin{array}{l}\text { - Texts } \\
\text { - Attitude DO } \\
\text { - Engagement DO } \\
\text { - Verbal scaffolding } \\
\text { - Lesson plans }\end{array}$ \\
\hline $\begin{array}{l}\text { Difficulty in identifying } \\
\text { ideology and situating } \\
\text { ideological positions within } \\
\text { the discursive field of } \\
\text { US culture }\end{array}$ & $\begin{array}{l}\text { - Participants will be able } \\
\text { to construct fine-grained } \\
\text { profiles of target audiences, } \\
\text { will infer ideological } \\
\text { intentions and draw } \\
\text { connections between } \\
\text { those and ideologies } \\
\text { in US culture. } \\
\text { - Participants will engage } \\
\text { in ideological critique }\end{array}$ & $\begin{array}{l}\text { - Appraisal analysis of taken- } \\
\text { for-grantedness } \\
\text { - Analysis of imaginings of the } \\
\text { nation and social groups } \\
\text { represented in texts } \\
\text { - Analysis of rhetorical strategies } \\
\text { (persuasion vs. identification) } \\
\text { - Ideological critique } \\
\text { - Declarative knowledge of US } \\
\text { ideologies and institutions }\end{array}$ & $\begin{array}{l}\text { - Texts } \\
\text { - Verbal scaffolding } \\
\text { - Verbal scaffolding } \\
\text { - Visuals } \\
\text { - Critical reading worksheets } \\
\text { - Lesson plans }\end{array}$ \\
\hline
\end{tabular}


The intervention was organized around the target interpretive processes and analytic constructs used to represent language processing discursively and scaffold critical reading processes. Knowledge of specific US ideologies and critical theory was organized around such processes. The analytic processes and constructs were those of Appraisal Theory, an offshoot of the Sydney School of Systemic-Functional Linguistics (WHITE, 2004; MARTIN; WHITE, 2005; MARTIN; ROSE, 2007). Constructs of contemporary rhetoric such as identification (BURKE, 1969) and imagining (ANDERSON, 1983; ASEN, 2002) were also used. Underlying the initial design solution is a presumption that Appraisal and rhetorical analyses as instantiated in the meditational means would scaffold discursively the target text processing behaviors that I assumed would produce the desired outcomes. Note that this paper reports only on the implementation of the part of the intervention focusing on Attitude analysis and its connection to rhetorical inferences of authorial positions and target/constructed audiences.

The meditational means included:

- a series of journalistic political opinion texts reflecting a variety of ideological positions in the US cultural context;

- two kinds of discourse organizers (DOs); discourse organizers are charts whose layout encourages specific kinds of semantic parsing of textual segments. They are not the same as discouse-structure graphic organizers [DSGOs (JIANG; GRABE, 2007)]. The DOs used in this study encouraged identification and parsing of language around two sub-systems of Appraisal: Attitude and Engagement;

- visual aids representing the Appraisal sub-systems of Attitude and Engagement;

- critical reading worksheets, which contained questions about authorial intentions, positions, and underlying ideologies; the participants answered two of these for each text: one prior to performing Appraisal analysis and another after performing Appraisal analysis;

- verbal scaffolding of Appraisal parsing and rhetorical inferences.

Fuller descriptions and exemplars of these meditational means can be consulted in Perales Escudero (2011). I implemented the intervention with a group of 27 undergraduate, pre-service EFL teachers at USM. It took the form of a CDA summer class. I taught this class for 45 hours during the months of July and August of 2010. The students took the English version of the PISA test 
to assess their reading ability in English. They also took Hernandez's (2008) implicit theories of reading questionnaire to determine if they were likely to be critical readers before the intervention. Most students were considered highintermediate to advanced readers, and only one adhered to an epistemic model, the constructive one, that suggested the student would be a critical reader. Participants answered a reading habits questionnaire developed for the study. Twenty-six of them reported not being used to reading journalistic political opinion texts and not being interested in politics at all.

The data sources were transcripts of classroom discourse (both wholeclass and small-group), recording of post-session feedback sessions with focused groups of participants, participants completed DOs and critical reading worksheets, and a design log I kept. Participants' oral data were transcribed using Jeffersonian conventions. ${ }^{2}$ I analyzed these data sources using coding categories I developed based on constructs from CT, critical reading, inferential comprehension, and SFL. I used directed qualitative coding (HSIEH; SHANNON, 2005), which means that I added additional categories as they emerged from the data. The coding categories included Attitude parsing, Attitudinal polarity, Engagement, Impromptu changes, Rhetorical inferences, Rhetorical strategies, Ideological critique, Attractor states, Control parameters, Change/Persistence Across data sources, Change/ Persistence across time.

\section{Results and Discussion}

Attractor states and control parameters were identified in participants' inferential comprehension as evidenced in their answers to worksheet questions and classroom discourse. When engaging in inferential comprehension, the participants' interpretive repertoires were initially driven to attractor states of implausible interpretations: a majority of the participants repeatedly made implausible inferences about authorial positions, intentions, and targeted audiences with the first text in the sequence. In the text "Perez Hilton, the foul face of gay marriage",

\footnotetext{
${ }^{2}()=$. one second or shorter pause, $(\# \mathrm{sec})=$ a pause longer than one second, (words) $=$ the segment between single curved parentheses isn't clearly audible, so what's written is the transcriber's best guess of what was said, ((cursive) $)=$ nonverbal data such as movements, CAPITALS = rise in volume, ? = rise in pitch at the end of an intonational contour, :::: = elongation of the sound place before the successive colons, $[\ldots]=$ elided turns in an excerpt.
} 
political blogger Matt Barber lambasts gay media critic Perez Hilton for having disqualified Carrie Prejean (Miss California) from the 2007 Miss USA beauty pageant after she stated she was against gay marriage. Barber never says explicitly that he is against gay marriage himself, but his systematic negative judgments of Hilton and those he aligns with him, coupled with his systematic positive judgments of Carrie Prejean, are grounds to infer that he opposes gay marriage. Further, the strong force of Barber's judgments against Hilton and supporters of gay marriage along with the absence of engagement with pro-gay marriage arguments suggests that he addresses/constructs an audience that is already in agreement with his position. From that perspective, his goal is to excite that audience's feelings of indignation at Hilton's treatment of Prejean, and incite hatred towards Hilton and, more generally, the pro-gay marriage camp. The completed attitude DO is shown in FIG. 2:

\begin{tabular}{|l|l|l|}
\hline Attitudinal language (polarity) & Source & Focus \\
\hline Foul (-) & Author & Perez Hilton, gay activism \\
Lovely (+) & Author & Carrie Prejean \\
Talented (+) & Prejean & Prejean's answer \\
No offense (+) & Author & Hilton's expected answer \\
Sanitized (-) & Author & Hilton \\
Creepy (-) & Author & Hilton \\
Blubber (-) & Author & Hilton \\
Fussy little baby (-) & & \\
Hate-filled (-) & Author & Hilton's response \\
Mysoginistic (-) & Author & Defense of Hilton's response \\
Disgraceful (-) & & by liberals, the media, and \\
& & organized homosexuality \\
& Hilton & Prejean \\
Dumb bitch (-) & Author & Hilton \\
Yammered (-) & Nora O'Donnell & Hilton \\
Sympathetic (-) (invoked) & Hilton & Prejean \\
Insult (-) & Author & Hilton's thought of insulting \\
Vile (-) & & Criticism of Prejean \\
& Author & Prejean \\
Bash-fest (-) & Norah O'Donnell & \\
Criticize (-) &
\end{tabular}

FIGURE 2 - Completed Attitude DO for Barber (2010), modified from the original Attitude DO by Wallace (2003) 
On day 2 of the intervention, participants read Barber's text twice: once prior to doing Appraisal analysis with the Attitude DO, and a second time after the Appraisal analysis. Both times they answered critical reading questions in the worksheet. Before the first reading, they were introduced to the text by asking background knowledge questions and teaching key vocabulary before reading. These questions asked participants to identify the author's position about gay marriage, and also the kind of audience the text constructed/was addressed to.

Prior to working with the DO, only four of the 27 participants responded plausibly that the author was against gay marriage. The remaining 23 thought the author was either neutral or in favor of gay marriage. After performing Appraisal analysis on the text, another 12 participants shifted to plausible inferences, i.e. their systems of comprehension shifted to a different attractor state, while 11 still answered that the author was either in favor of gay marriage or neutral about it, i.e. their comprehension revolved around attractor states of implausible interpretations.

Examples 1-4 suggest that the application of low standards of coherence (VAN DEN BROEK et al., 2002) ${ }^{3}$ and the construction of incomplete textbases (KINTSCH, 1998) acted as control parameters motivating the 11 participants who shifted to plausible inferences. These low standards of coherence might stem from their not being used to processing evaluative language at the discourse level.

(1) It changed my mind about the text. I had another opinion which was not really accurate. I first thought that the author was in favor of gay marriage [Luis' written comment on session 2 evaluation worksheet].

(2) It was a good way to find attitude with texts that are not so explicit about author's opinions [Luis' focused group comment].

(3) When I read the text, I thought the author agreed with gay marriage. But when I was doing the analysis, I realized he didn't [Patricia's written comment on session 2 evaluation worksheet].

(4) This class influenced the ways I read texts, because as a reader, I used to read texts superficially and I only accepted what I could understand. What I could not I just skipped. I used to answer comprehension questions in a

${ }^{3}$ Standards of coherence are "readers' knowledge and beliefs about what constitutes good comprehension" (VAN DER BROEK et al., 2002, p. 137). 
simple way. But now, the teacher and the class have made me think that it is not always possible to catch a text's important points at once. I have to infer and look deeply into the text in order to understand [anonymous post-intervention feedback].

Specifically, comment 4 suggests that the prevalent ways of teaching and practicing EFL reading in the setting encourage building textbases by applying low standards of coherence and fixing on a few words here and there. This piece of data appears to conflict with the fact that participants were good to very good readers per the PISA test, except that in that test they showed they weren't good readers for questions requiring inferences of implicit authorial intentions in a complex narrative text where parsing of evaluative language was key for making those inferences (see Perales Escudero, 2010, for a discussion of Appraisal-based rhetorical inferences in the PISA test). This kind of parsing was also required for reading the target texts in this intervention. Thus, it appears that the initial condition of these participants' interpretive repertoires did not include the patterned processes needed to fix on and parse evaluative language in political opinion articles.

The application of rhetorical genre knowledge, or beliefs about the communicative functions of genres and evaluative language, also acted as a control parameter driving participants' inferences to attractor states of implausible rhetorical inferences. This control parameter manifested itself in two assumptions: assuming that all journalistic texts are narrative/informative, and assuming that evaluative language always works rhetorically as it does in scolding or sermons.

The data show that some of the participants assumed that journalistic articles are all merely narrative or informative, hence their answers that the author was neutral. This assumption is likely to stem from students' previous engagement with truly informative-narrative journalistic genres. Recall that they reported not reading political opinion texts, so they generalized their knowledge of genres familiar to them to the target genre.

Below is a segment of my conversation with Jaime, a participant who said the author was neutral after having completed the Attitude DO accurately. I realized that Jaime had written "the author is neutral" in response to the question about the author's position on gay marriage, so I proceeded to ask why he thought that way. 
(5) 1 Jaime: he's not giving any uh comment for or against Prejean's comments (.) but uh (.) for me (.) he's trying to (.) say all the negative things that she said (.) without helping her

$[\ldots]$

$2 \mathrm{~T}$ : but (.) is it justified to infer that he agrees with Carrie Prejean?

3 Jaime: no

$4 \mathrm{~T}$ : so that's your opinion. (.) maybe or maybe not.

((Jaime looks back at the DO and the text)) (4 secs)

5 Jaime: OH::: YEAH::: (.) it's just that that when I read the text (.) I thought he was neither in favor nor (.) against Carrie Prejean's comments (.) but (.) as you said if we analyze the (.) uh the chart and the (text) (.) well (.) it shows that he's (.) uh (.) all his comments about Carrie Prejean are positive so he might be (.) uh he may agree with her (.) yeah (.) $[\ldots]$

6 Jaime: my first impression was (.) that he's only narrating without taking a position but uh (.) well (.) having analyzed it (.) it changes

Jaime's utterances reveal an initial interpretation of the text as narrative ("my first impression was that he was only narrating") or merely informative ("he's not giving any uh comment for or against Prejean's comments... I thought he was neither in favor nor against Prejean's comments"). It appears that Jaime assumes that all journalistic texts are narrative/informative and thus neutral, presumably because of a lack of awareness of the rhetorical practices and purposes indexed by the target genre (he indicated he does not read political opinion texts in the reading habits survey). That this belief might be operating as a control parameter influencing his and others' interpretations of this text is supported by the fact that four other participants expressed similar beliefs vis-à-vis the narrative/informative quality of all journalistic texts. Those participants had also indicated that they had no prior experience with reading political opinion texts.

I explained to the class that the texts we were reading were opinion texts rather than informative ones, and that it was appropriate to make inferences about authors' positions and intentions even if those are not explicit. These explanations, coupled with the DO analysis, appeared to have an effect in participants' interpretive repertoires as indicated by the fact that the number of participants making implausible inferences for the subsequent texts was lower (see TAB. 2). 
TABLE 2

Participants producing implausible inferences of authorial position

\begin{tabular}{|l|l|}
\hline Text & Participants \\
\hline McLeod (2007) & None \\
Calhoun (2007) & None \\
Wendland (2006) & Natividad, Patricia, Nancy \\
Blankenhorn (2008) & Gladys \\
\hline
\end{tabular}

The second rhetorical genre knowledge assumption, that evaluative language in political opinion texts works rhetorically as it does in scolding or sermons, was apparent in participants' inferences regarding the overall construction of an audience as agreeing or disagreeing with the author. I call this the global reading position. As explained above, the presence of highly graduated negative judgments of Hilton and supporters of gay marriage is grounds to infer that the author does not attempt to persuade them to change their mind. This interpretation is further buttressed by the exclusion of progay marriage perspectives from the text. Rather, those judgments and exclusion suggest that Barber writes for those who already oppose gay marriage in order to exacerbate their indignation at the offensive behavior of gay marriage activists. ${ }^{4}$ Then, to me, the global reading position is one of agreement with Barber's stance. However, this was not what participants inferred.

Interestingly, only six of twenty students present in the class characterized the global reading position as aligned with the author, like I did. By contrast, seven students thought that the text was written for a dissenting audience, i.e. those who would align with Hilton and favor gay marriage. Another seven students answered that the text was written for anyone.

${ }^{4}$ This interpretation is based on Hauser's (1998) rhetorical model of the public sphere. To counter Habermas' emphasis on rationality in the public sphere, Hauser proposes what he calls a rhetorical model of the public sphere, one where groups of people assemble around ideological positions and each group defines its own norms of dialog for both in-group and out-group consumption. Under this perspective, the rhetorical force of an in-group argument depends not on its persuasive rationality but on how well it resonates with a group's concerns and shared meanings. Conversely, an out-group argument would seek to incorporate that group's meanings and concerns. Because Barber's argument does not incorporate but violently attacks gay-marriage activists' perspectives (his out-group), it can be said to be directed to his in-group (gay marriage opponents). 
The global reading position inferences of these diverging groups appear to emerge from different assumptions about the rhetorical nature of this text. Those positing a dissenting global reading position did so because of their assumption that negative judgments of a discursive participant signal that those participants are being addressed. Below are Octavia's and Karen's answers:

(6) The author is focusing on an audience that agrees with Perez Hilton's attitude. I think he's trying to persuade the people that share Perez Hilton's opinions in order to change their minds and make them realize about the Perez Hilton's wrong comments [Octaviàs answer to question 4, critical reading worksheet, class 3].

(7) I think the text is written for those who are against the author's attitude because he is always evidencing [sic] the bad behavior of people who agree with Perez Hilton [Karen's answer to question 4, worksheet 4, critical reading worksheet, class 3].

During oral feedback, Karen and other students volunteered that the notion that texts were addressed to specific audiences was new to them.

(8) Karen: the concept of audience was new to me (.) I had never thought about that before [Karen's focused group comment]

She appears to have held a tacit assumption that texts are written for anyone who reads them. Yet, she answered that the text is written for an audience that would sympathize with Perez Hilton because the author is trying to represent Perez Hilton's wrong behavior to them (example 3 above). This kind of exchange where discursive participants who are judged negatively are the target audience for the text is typical of scolding, or church sermons. In instances of scolding, the Appraised, or object of attitude, and the Appraisee, or hearer of the attitudinal message, are conflated as shown in FIG. 3.

\section{Appraisal}

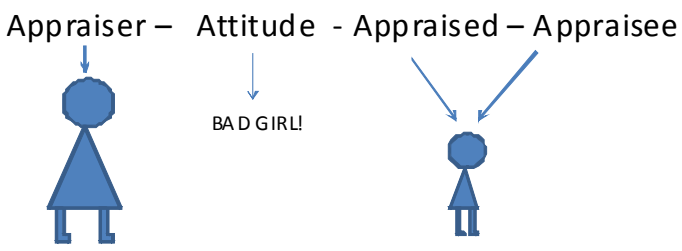

FIGURE 3 - Conflation of Appraised-Appraisee in oral scolding 
This kind of conflation of Appraised and Appraisee strikes me as infrequent in written, public, journalistic political opinion pieces, although it may be found in other journalistic genres such as letters to the editor. Karen's contributions suggest that, when exposed to an unfamiliar task whose reasoning parameters they did not know, she and other participants generated inferences that were presumably based on their previous discursive experiences with genres containing the kind of highly graduated negative judgments found in Barber. These genres include oral scolding and sermons.

Similarly, Luis, who answered that the text was written for anyone, did so guided by the assumption that "careless" use of language, by which he probably means highly graduated negative judgment, signals a lack of engagement with a specific audience:

(9) I don't think that he's aiming at a specific audience. I know this because he's not being careful about what he says... it's like a TVNotas article. [Luis' answer to question 4, critical reading worksheet, class 3].

Luis said that he saw similarities between Barber's prose style and that of the popular Mexican yellow-press magazine TVNotas (example 9 above). He reported believing that this writing style is aimed at generating controversy and scandal in all kinds of readers, without addressing any specific reading position. This is a fair assumption: TVNotas is not part of the rhetorical public sphere (HAUSER, 1998); its writers and texts do not take positions on issues of public governance. What Luis does not perceive is that Barber's text, unlike TVNotas articles, does partake in the rhetorical public sphere and thus different assumptions apply when interpreting its rhetorical context and purposes.

It appears then that the presence of highly graduated evaluative language triggered the activation of rhetorical genre knowledge corresponding to the genres where the participants had encountered this kind of language before: scolding, sermons, and a Mexican yellow press magazine. The application of rhetorical genre knowledge to this reading task acted as a control parameter driving their global reading position inferences. The participants used their non-target prior rhetorical genre knowledge as thinking parameters to meet the demands of this unfamiliar task because they did not have knowledge of the target genre; they reported not reading political texts and not being interested in politics at all. The demand to conduct a new sociocognitive task (inferring audience in an unfamiliar genre) seems to have driven the students' interpretive repertoires to the edge of chaos, i.e. the previously ordered, stable 
state of the repertoires was thrown off-balance by the task, creating the conditions for the reorganization of the repertoires-qua-complex systems.

In the discussion that followed individual answering of the critical reading questions, I explained that a goal of critical reading is to generate plausible inferences that can be verified from the text's language. I also explained explicitly during day 3 and subsequent sessions that the presence of strong evaluations signals the construction of an audience aligned with the author, especially when the grounds for such evaluations are not explicit and are therefore assumed to be shared. These explanations appear to have been powerful enough to re-organize the participants' interpretive repertoires and generate new patterned processes: none of the participants who thought that there was no specific audience for Barber responded similarly to questions about the ideal reader constructed by the subsequent texts. Further, Karen and the other participants who inferred Barber's global reading position implausibly showed success in constructing plausible representations of global reading positions in subsequent texts. They also supported their interpretations with evidence grounded in the linguistic graduation of attitude.

(10) Karen: I think it's someone who is in favor of same sex marriage because the kind of vocabulary used in the text (.) is neutral

These new patterned processes were visible after instruction on the generic and rhetorical effects of highly graduated language, and thus may have emerged partially from such instruction as suggested by Karen's comment below.

(11) Karen: I didn't know that you could infer the ideal reader by looking at how strong the language is (.) that's new for me

The differences between Karen's answers in examples 7 and 10, and her assertions in 8 and 11, suggest that it was the intervention which led her to develop a new assumption about public discourse. While she first understood that highly graduated judgment signals that the appraised of such language is being addressed (see example 11 above), she switched to an assumption, aligned with that promoted by the intervention, that the presence of such language is grounds to infer that a reader aligned with the author is being constructed. In other words, her interpretive repertoire changed in response to instruction. That no further examples of implausible global reading positions inferences appear in other participants' answers indicates the same change occurred in 
other participants. Therefore, this is evidence of emergence of the targeted processes and contributes to validating the core tenet of the instructional theory, namely that Appraisal and rhetorical analyses can support the making of plausible rhetorical inferences.

Participants' pieces of anonymous post-intervention feedback suggest that their interpretive repertoires indeed co-evolved with the intervention and new patterned processes emerged:

(12) During the summer term I also took two translation courses, then this course helped me a lot because, even though I didn't write the DOs for the articles we had to translate, I did the DOs mentally when I was reading the texts and so I realized what the author meant and it was easier to translate.

(13) Now, when reading an article, my mind subconsciously analyzes the important

(14) points like attitudes or feelings.

(15) I can recognize the polarity of words and that helps to know the author's position.

(16) The student can identify that in a simple paragraph there is a source and a focus of attitude.

\section{Final considerations}

CT's retrodiction-based research epistemology and the constructs of attractor states and control parameters were useful to characterize the initial conditions of the participants' interpretive repertories when applied to the reading tasks and the factors influencing their interpretive activity. They also contributed usefully to refine the prototheories of the design-based research process, as discussed below.

The goal of the intervention was to promote the emergence of new meaning-making capacities, namely generative rhetorical inferences. As predicted by the learning needs proto-theory, the initial condition of many participants' interpretive activity was characterized by attractor states of implausible inferences. The construct "attractor states" worked as a heuristic tool to describe the initial conditions of the participants' interpretive repertoires. As predicted by the instructional prototheory, Appraisal analysis was sufficient for eleven of the participants to produce plausible inferences. However, it wasn't for sixteen of the participants. For the first group of 
participants, the control parameters behind implausible inferences of authorial position were using low standards of coherence and the resulting construction of incomplete textbases. For the second group of participants, discourse analysis shows that applying conceptual frames pertaining to other genres, or non-target rhetorical genre knowledge, acted as a control parameter driving interpretive activity to attractor states of implausible authorial position and global reading position inferences.

Importantly, it was the CT conceptual apparatus that guided me to analyze classroom discourse to look for control parameters, i.e. discourse analysis was guided by the search for control parameters and the conceptualization of comprehension as a complex system. This way of investigating comprehension is substantially different from the psychological, quantitative paradigm that prevails in comprehension research.

The identification of these attractor states and control parameters has implications for the theorization of inferential comprehension, for the design of this intervention, and for L2 reading pedagogy. From a theoretical standpoint, the Construction-Integration (C-I) model of comprehension posits that the cognitive representation of a text emerges partially from parsing the text's language (KINTSCH, 1988; MCNAMARA; KINTSCH, 1996), and that readers may also make rhetorical inferences (HAAS; FLOWER, 1988; PERFETTI; MARRON; FOLTZ, 1996). However, the C-I does not include a characterization of the reasoning processes required to make generative inferences. I attempt one below.

The textbase and inferred rhetorical features can be understood as two levels of meaning in a scale, one semantic and the other pragmatic, with pragmatic meaning being at a higher level. The specific processes of emergence, or passage, from semantic meaning to the specific kind of pragmatic meaning addressed here were not known with precision. The analysis of examples 111 suggests that, rhetorical genre knowledge acting as a control parameter accounts for the process of scalar emergence from semantic to pragmatic meaning.

Paltridge (1997) and Fernandez Toledo (2005) had suggested that nonstructural, cognitive/pragmatic aspects of genre knowledge could play a role in comprehension, and this study confirms and refines their suggestions. The study thus adds to our growing understanding of the role of genre in comprehension, which is still a poorly understood and under-researched area (GRABE, 2009). The study then shows the power that a focus on retrodiction 
and unpredictable factors, as revealed by a search for attractor states and control parameters, can have for researching comprehension while intervening in it.

Examples 1 through 15 above and my discussion of the impromptu changes made to the design solution indicate that co-adaptation occurred between the participants and the design solution. The identification of control parameters, attractor states, and changes to the intervention resulted in modifications to the proto-theories. Because the modified proto-theories incorporate feedback from the implementation cycle, they can be called domain theories (EDELSON, 2002). These are summarized in TAB. 3.

\section{TABLE 3}

Additions to the learning and instructional prototheories resulting from data analysis. $\sqrt{ }=$ An element implemented as a impromptu adaptation, ${ }^{*}=$ an element not implemented but recommended for inclusion in the final design solution.

\begin{tabular}{|c|c|c|c|}
\hline & $\begin{array}{c}\text { Learning Needs Domain } \\
\text { Theory }\end{array}$ & $\begin{array}{l}\text { Learning Outcomes } \\
\text { Domain Theory }\end{array}$ & Instructional Domain Theory \\
\hline 1 & $\begin{array}{l}\text { Students use low standards } \\
\text { of coherence when reading } \\
\text { political opinion texts and } \\
\text { develop partial textbases. }\end{array}$ & $\begin{array}{l}\text { Students will engage } \\
\text { deeply with evaluative } \\
\text { language, and will } \\
\text { construct fuller textbases }\end{array}$ & $\begin{array}{l}\text { Attitude metalanguage and attitude DOs } \\
\text { scaffold the strategies and skills required to } \\
\text { develop fuller textbases. }\end{array}$ \\
\hline 2 & $\begin{array}{l}\text { Students are not used to } \\
\text { checking their emerging } \\
\text { interpretations against } \\
\text { evidence from the text. }\end{array}$ & $\begin{array}{l}\text { Students will check their } \\
\text { interpretations against } \\
\text { evidence from the text. }\end{array}$ & $\begin{array}{l}\text { Attitude metalanguage and attitude DOs } \\
\text { scaffold the emergence of this metacognitive } \\
\text { strategy. Verbal discussion may be helpful } \\
\text { as well. }\end{array}$ \\
\hline 3 & $\begin{array}{l}\text { Students use knowledge of } \\
\text { previous genres and } \\
\text { discursive experiences to } \\
\text { interpret texts in the target } \\
\text { genre. This knowledge is } \\
\text { inadequate for this task. } \\
\text { Students need different } \\
\text { rhetorical knowledge and } \\
\text { genre knowledge to be able } \\
\text { to use the results of attitude } \\
\text { analysis to make plausible } \\
\text { rhetorical inferences. }\end{array}$ & $\begin{array}{l}\text { Students will be able to } \\
\text { tell the different } \\
\text { rhetorical situations and } \\
\text { purposes indexed by } \\
\text { different journalistic and } \\
\text { non-journalist genres as } \\
\text { well as public sphere vs. } \\
\text { other sphere genres. }\end{array}$ & $\begin{array}{l}\text { Explanations about the role of highly } \\
\text { graduated evaluative language in } \\
\text { constructing audiences help global reading } \\
\text { position inferences. } \sqrt{ } \\
\text { Explanations about the appropriateness of } \\
\text { making plausible inferences help students } \\
\text { to develop a strategy to want to make those } \\
\text { inferences. } V \\
\text { Explanations about the connection between } \\
\text { the spheres of communication and } \\
\text { different journalistic genres help students } \\
\text { make plausible rhetorical inferences.* } \\
\text { Comparing samples of several genres from } \\
\text { different spheres can potentially expand } \\
\text { rhetorical and genre knowledge.* }\end{array}$ \\
\hline
\end{tabular}

As can be seen in the first addition to the prototheories in TAB. 3, having identified use of low standards of coherence as a control parameter driving students to construct impoverished textbases has contributed to refining the learning prototheories and the instructional prototheory. While 
the initial prototheory already pointed at lack of engagement with the text's language, this control parameter and learning need emerges with more clarity from students' reports of changes from superficial to close reading. With regard to the second addition concerning metacognition, this was an unexpected finding that contributes significantly to understanding learners' needs in this design setting. Further, their reports that instruction led to metacognition is also significant in informing reading teachers and scholars of the potential of SFL tools to produce this highly desirable outcome.

The third addition concerning rhetorical genre knowledge was also unexpected. Although I somewhat suspected that students in the setting were not used to reading political texts, the extent to which they compensated for their lack of relevant knowledge with rhetorical knowledge from other genres was unexpected. Also unexpected was their being unaware that texts are addressed to and construct specific audiences. Further, the resistance to make rhetorical inferences of unstated authorial position was also unexpected. These are then important contributions to the learning prototheories. That explanations worked to change participants' interpretive repertoires in the desired directions is also a relevant contribution to the instructional prototheory.

However, no explicit exploration of the distribution and roles of genres across discursive spheres (e.g. public, private, religious) was undertaken. Such exploration could be very beneficial to build the desired kinds of genre and rhetorical knowledge, hence the recommendation to include activities oriented to exploring genres across spheres in the design framework. Further research with other genres that incorporate evaluative language, such as research articles, is needed to clarify the applicability of the design framework presented here to other reading situations. Additional research is also needed to continue to refine the framework for the target genre.

This study has other implications for EFL reading pedagogy. According to Grabe (2009) and Han \& D'Angelo (2007), prevalent L2 reading pedagogical practices within the communicative approach de-emphasize engagement with a text's language and emphasize predicting content from pictures and headings, and vocabulary guessing strategies. The results of this study indicate that such practices might influence the low standards of coherence used by the participants. In addition, there doesn't seem to be much variety in the genres included in commercial, global EFL textbooks, which suggests that current-traditional EFL reading instruction does not contribute much to the development rhetorical genre knowledge for a wide variety of 
genres. The results of this study indicate that its instructional theory can be an effective, adaptable means to promote higher standards of coherence and rhetorical genre knowledge in EFL readers.

I have presented a qualitative DBR study, which is a departure from the traditionally quantitative way of conducting DBR and reading comprehension research. I hope to have shown that, through discourse analysis of texts and talk and the use of a CT-based epistemology and constructs, relevant pedagogical lesson can be learned, and theoretical points can be made about the processes of inferential comprehension.

\section{References}

AGUILAR RIVERA, J. A. El sonido y la furia: La persuasión multicultural en México y en Estados Unidos. México, D.F.: Taurus, 2002. 296 p.

ANDERSON, B. Imagined Communities: Reflections on the Origins and Spread of Nationalism. London; New York: Verso, 1983. 240 p.

ASEN, R. Imagining in the Public Sphere. Philosophy and Rhetoric, v. 35, n. 4, p. 345-367, 2002.

BARBER, M. Perez Hilton: The Foul Face of Gay Activism. Conservative News Service, 2007. Available at: <http://www.cnsnews.com/node/47153>. Retrieved April 102010.

BERNHARDT, E. Understanding Advanced Second Language Reading. New York: Routledge, 2011. 240 p.

BLANKENHORN, D. Protecting Marriage to Protect Children. Available at: <http://www.latimes.com/news/opinion/commentary/la-oe-blankenhorn192008sep19,0,6057126.story >. Retrieved March 172010.

BROWN, J. Self and Process: Brain States and the Conscious Present. New York: Springer Verlag, 1991. $201 \mathrm{p}$.

BURKE, K. A Rhetoric of Motives. Berkeley; Los Angeles: University of California Press, 1969. $356 \mathrm{p}$.

BUSSENIERS, P.; GILES, D.; NÚÑEZ, P.; SÁNCHEZ, V. The research proposal at the B.A. in English of a major public university in East Mexico: A genre and register analysis of student writing. In: PERALES M. (Ed.). Literacy in Mexican Higher Education: Texts and Contexts. Puebla: BUAP, 2011 p. 74-117.

CALHOUN, W. H. The North American Union: It’s Coming. Available at: <http:/ /www.canadafreepress.com/2007/calhoun032107.htm>. Retrieved April 6. 2010 . 
CHOULIARAKI, L.; FAIRCLOUGH, N. Discourse in Late Modernity: Rethinking Critical Discourse Analysis. Edinburgh, Scotland: Edinburgh University Press, 1999

$\mathrm{COBB}, \mathrm{P}$. Supporting the improvement of learning and teaching in social and institutional contexts. In: CARVER, S.; KLAHR, D. (Eds.). Cognition and Instruction: Twenty-Five Years of Progress. Cambridge, MA: Lawrence Erlbaum, 2001. p. 455-478.

COBB, P.; CONFREY, J.; DISESSA, A.; LEHRER, AR.; SCHAUBLE, L. Design Experiments in Educational Research. Educational Researcher, v. 32, n. 1, p. 9-13, 2003.

COLLINS, A. The Changing Infrastructure of Educational Research. In: LAGEMANN, E.; SHULMAN, L. (Eds.). Issues in Education Research: Problems and Possibilities. New York: Jossey-Bass, 1999. p. 289-298.

DESIGN-BASED RESEARCH COLLECTIVE. Design-based research: An emerging paradigm for educational inquiry. Educational Researcher, v. 32, n. 1, p. 5-8, 2003.

DÍAZ, J. L. A Patterned Process Approach to Brain, Consciousness and Behavior. Phylosophical Psychology, n.10, p. 179-195, 1997.

DÍAZ, J. L. El cerebro, enjambre de la conciencia. In: FLORES VALDÉS, J. F.; MARTÍNEZ MEKLER, G. (Eds.). Encuentros con la complejidad. México, DF: Siglo XXI, 2011. p. 178-198.

DÍAZ, J. L. La conciencia viviente. México, DF: Fondo de Cultura Económica, 2007. $625 \mathrm{p}$.

DÍAZ, J. L. Mind-body Unity, Dual Aspect, and the Emergence of Consciousness. Phylosophical Psychology, n. 13, p. 393-403, 2000.

EDELSON, D. C. Design Research: What We Learn When We Engage in Design. The Journal of the Learning Sciences, v. 11, n. 1, p. 105-121, 2002.

FAIRCLOUGH, N. Analysing Discourse: Textual Analysis for Social Research. London; New York: Routledge, 2003. 288 p.

FAIRCLOUGH, N. Critical Discourse Analysis. London: Longman, 1995. 608 p. FERNANDEZ TOLEDO, P. Genre analysis and reading of English as a foreign language: Genre schemata beyond text typologies. Journal of Pragmatics, v. 37, n. 7, p. 1059-1079, 2005.

FILLMORE, C. J. Frame Semantics and the Nature of Language. CONFERENCE ON THE ORIGIN AND DEVELOPMENT OF LANGUAGE AND SPEECH. Annals of the New York Academy of Sciences. v. 280, 1976. p. 20-32. 
GIBBONS, P. Scaffolding Language, Scaffolding Learning. Portsmouth, NH: Heinemann, 2002. 176 p.

GRABE, W. Reading in a Second Language: Moving from Theory to Practice. Cambridge: Cambridge University Press, 2009. 484 p.

GREENO, J. G. Theoretical and Practical Advances Through Research on Learning. In: GREEN J.; CAMILLI G.; ELMORE P. B. (Eds.). Handbook of Complementary Methods in Education Research. New York: Routledge, 2006. p. 795-822.

HAAS, D; FLOWER, L. Rhetorical reading strategies and the construction of meaning. College Composition and Communication, v. 39, n. 2, p. 167-183, 1988.

HAN, Z.; D'ANGELO, A. Balancing Between Comprehension and Acquisition: Proposing a Dual Approach. In: HAN, Z.; ANDERSON, N. J.; FREEMAN, D. (Eds.). Second Language Reading Research and Instruction: Crossing the Boundaries. Ann Arbor, MI: The University of Michigan Press, 2007. p. 173-191.

HANLON, R. E. Cognitive Microgenesis: A Neuropsychological Perspective. New York: Springer Verlag, 1991. 343 p.

HAUSER, G. Vernacular Dialogue and the Rhetoricality of Public Opinion. Communication Monographs, v. 65, n. 2, p. 83-107, 1998.

HAZELRIGG, A. C. Second Language Reading Research: A Critical Review. ERIC. Available at: <http://www.eric.ed.gov/ERICDocs/data/ericdocs2sql/ content_storage_01/0000019b/80/3e/c4/72.pdf >. Retrieved May 52009.

HERNÁNDEZ, G. Teorías implícitas de lectura y conocimiento metatextual en estudiantes de secundaria, bachillerato y educación superior. Revista Mexicana de Investigación Educativa, v. 13, n. 38, p. 737-771, 2008.

HSIEH, H. F.; SHANNON, S. E. Three Approaches to Qualitative Content Analysis. Qualitative Health Research, v. 9, n. 15, p. 1277-1288, 2005.

HYON S. A Genre-Based Approach to ESL Reading: Implications for North American and Australia. Unpublished doctoral dissertation. Ann Arbor, MI: University of Michigan, 1995. 366 p.

JIANG, X; GRABE, W. Graphic organizers in reading instruction: Research findings and issues. Reading in a Foreign Language, v. 19, n. 1, p. 34-55, 2007. KINTSCH, W. Comprehension: A Paradigm for Cognition. New York: Cambridge University Press, 1998. 480 p.

KLEIN, P. D.; ROSE, M. A. Teaching argument and explanation to prepare junior students for writing to learn. Reading Research Quarterly, n. 45, p. 433-461, 2010. KODA, K. Insights into Second Language Reading. Cambridge: Cambridge University Press, 2005. 340 p. 
KRESS, G. Linguistic Processes in Sociocultural Practice. Oxford: Oxford University Press, 1989. $101 \mathrm{p}$.

KRETZSCHMAR, W. The Linguistics of Speech. Cambridge: Cambridge University Press, 2009. 308 p.

LARSEN-FREEMAN, D. Reflecting on the Cognitive-Social Debate in Second Language Acquisition. The Modern Language Journal, n. 91, p. 773-787, 2007. LARSEN-FREEMAN, D.; CAMERON, L. Complex Systems and Applied Linguistics. Oxford: OUP, 2008. 287 p.

LOBATO, J. How Design Experiments Can Inform a Rethinking of Transfer and Vice Versa. Educational Researcher, v. 1, n. 32, p. 17-20, 2003.

MAINZER, K. Thinking in Complexity: The Computational Dynamics of Matter, Mind, and Mankind. New York: Springer Verlag, 1994. 476 p.

MARTIN, J. R.; ROSE, D. Working with Discourse. London: Continuum, 2007. $368 \mathrm{p}$.

MARTIN, J. R.; WHITE, P. R. R. The Language of Evaluation. New York: Palgrave Macmillan, 2005. 256 p.

MCLEOD, J. Debut of the Amero. Available at: <http://www.canadafreepress. com>. Retrieved January 112009.

MCNAMARA D.; KINTSCH, W. Learning from texts: Effects of prior knowledge and text coherence. Discourse Processes, n. 22, p. 247-288, 1996.

PALTRIDGE, B. Genre, Frames and Writing in Research Settings. Amsterdam: John Benjamins, 1997. 192 p.

PERALES ESCUDERO, M. D. Teaching and Learning Critical Reading at a Mexican University: An Emergentist Case Study. 2011. 304 p. (Doctoral dissertation) - Department of English and School of Education, University of Michigan, Ann Arbor, 2011.

PERALES ESCUDERO, M. D. Una aproximación a la lectura retórica: la prueba PISA y los estudiantes de la licenciatura en idiomas. Perspectivas Docentes, segunda época, n. 43, p. 42-52, 2010.

PEREDO MERLO, M. A. Representaciones docentes del déficit lector de los estudiantes. Revista Mexicana de Investigación Educativa, v. 48, n. 16, p. 221-242, 2011.

PERFETTI, C.; MARRON, M. A.; FOLTZ, P. W. Sources of comprehension failure: Theoretical Perspectives and Case Studies. In: CORNOLDI, C.; OAKHILL, J. (Eds.). Reading Comprehension Difficulties: Processes and Interventions. Mahwah, NJ: Lawrence Erlbaum, 1996. p. 137-165. 
PETRINA, S. The Politics of Curriculum and Instructional Design/Theory/ Form: Critical Problems, Projects, Units, and Modules. Interchange: A Quarterly Review of Education, v. 1, n. 35, p. 81-126, 2004.

PRETORIOUS, E. English as a second language differences in anaphoric resolution: Reading to learn in academic context. Applied Psycholinguistics, n. 26, p. 521-539, 2005.

SCHOENFELD, A. H. Design experiments. In: GREEN, J.; CAMILLI, G.; ELMORE, P. B. (Eds.). Handbook of complementary methods in education research. New York: Routledge, 2006. p. 193-206.

STANLEY, R. M. The recognition of macrostructure: A pilot study. Reading in a Foreign Language, n. 2, p. 156-168, 1984.

STEPHENS, C. R. Lo que no es la complejidad. In: FLORES VALDÉS, J. F.; MARTÍNEZ MEKLER, G. (Eds.). Encuentros con la complejidad. México, DF: Siglo XXI, 2011. p. 13-47.

THELEN, E.; SMITH, L. A Dynamic Systems Approach to the Development of Cognition and Action. Cambridge, MA: The MIT Press, 1994. 408 p.

VAN DEN BROEK, P.; VIRTUE, S.; EVERSON, M.; TZENG, Y.; SUNG, Y. C. Comprehension and memory of science texts: Inferential processes and the construction of a mental representation. In: OTERO, J.; LEON, J. A.; GRAESSER, A. C. (Eds.). The psychology of science text comprehension. Mahwah, NJ: Lawrence Erlbaum Associates, Inc, 2002. p. 131-154.

WALLACE, C. Critical language awareness: Key principles for a course in critical reading. Language Awareness, v. 8, n. 2, p. 98-110, 1999.

WALLACE, C. Critical literacy awareness in the EFL classroom. In: FAIRCLOUGH, N. (Ed.). Critical Language Awareness. New York: Longman, 1992. p. 59-92.

WALLACE, C. Critical Reading in Language Education. New York: Palgrave Macmillan, 2003. 217 p.

WENDLAND, J. Immigration reform: Bush and republicans appeal to White supremacy. Political Affairs.Net . Available at: <http://www.opednews.com/ articles/opedne_joel_wen_060519_immigration_reform_3a_.htm $>$. Retrieved May 312011.

WERTSCH, J. Voices of the Mind: A Sociocultural Approach to Mediated Action. Cambridge, MA: Harvard University Press, 1993. 182 p.

WHITE, P. R. R. Un recorrido por la teoría de la valoración. Trad. Elsa Ghio. Appraisal Website, 2004. Available at: <http://www.grammatics.com/ appraisal>. Retrieved March 1, 2012.

Recebido em 01/08/2012. Aprovado em 26/11/2012. 